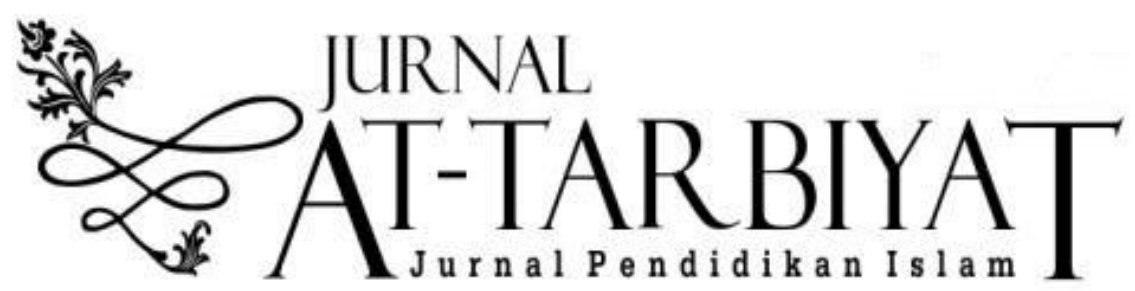




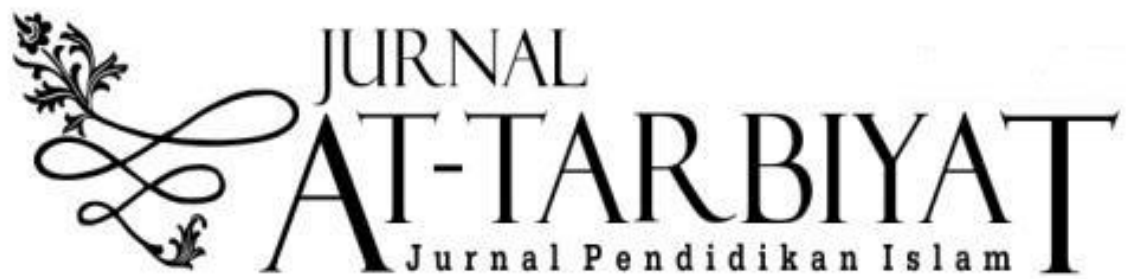

\section{Editorial Team:}

\section{Editor in-Chief}

Adi Wibowo, STAI An- Nawawi Purworejo

Editorial Board

Badrudin, UIN Sunan Gunung Djati Bandung Imam Machali, UIN Sunan Kalijaga Yogjakarta

Sri Rahmi, UIN Ar-Raniry Banda Aceh

A. Jauhar Fuad, IAI Tribakti Kediri

\section{Managing Editor}

Muhlil Musolin, STAI An- Nawawi Purworejo

\section{Editor}

Ita Nurmala Sari, STAI An- Nawawi Purworejo Ahmad Syafi'i, UIN Sunan Kalijaga Yogjakarta

Ulumuddin, Unwahas Semarang

Dwi Puji Lestari, STAI Al Hasyimiyyah Jakarta

Sri Sujarotun, STAI An- Nawawi Purworejo

Ali Murfi, UIN Sunan Kalijaga Yogjakarta

\section{Editorial Assistant}

Isnaini, STAI An- Nawawi Purworejo

Mujasim, STAI An- Nawawi Purworejo

\section{Alamat Redaksi:}

Prodi Manajemen Pendidikan Islam, STAIAN Purworejo Jl. Ir.H. Juanda No. 1 Berjan, Gebang Purworejo 54191 Jawa Tengah » Tel / fax : (0275)3128428. e-mail: jurnalattarbiyat@gmail.com http://jurnal.staiannawawi.com/index.php/At-Tarbiyat 


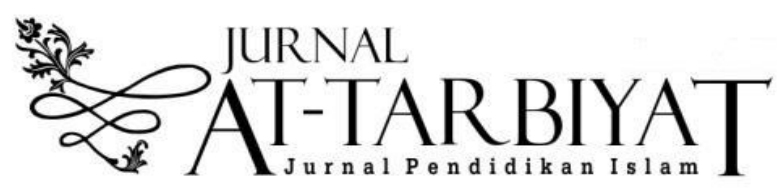

\section{Tabel of Content}

Implementasi Pendidikan Karakter dalam Keluarga Muslim (sebuah pendekatan sosiologis)

Hadi Santoso 1

Manajemen Ekstrakurikuler Dalam Upaya Pengembangan Diri Santri Pondok Pesantren Al-Luqmaniyyah Yogyakarta

Ahmad Hinayatulohi 25

Konsep Dasar Epistemologi Pendidikan Multikultural Dalam Islam Zainun Wafiqatun Niam.

Indeks Penulis

Ucapan Terima kasih Kepada Mitra Bebestari

Author Guideline. 


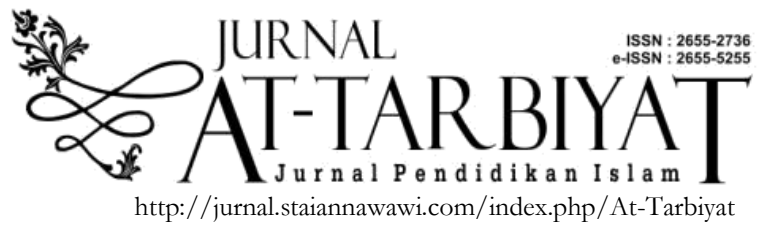

\title{
KONSEP DASAR EPISTEMOLOGI PENDIDIKAN MULTIKULTURAL DALAM ISLAM
}

\author{
Zainun Wafiqatun Niam \\ UIN Sunan Kalijaga Yogyakarta
}

\section{Abstrak}

Pendidikan sebagai sarana pengembangan potensi manusia dan pembentukan tatanan masyarakat harus diselenggarakan dengan prinsip kesetaraan dan keadilan. Prinsip tersebut didasarkan pada keniscayaan bahwa manusia hidup dalam lingkup perbedaan. Pendidikan Islam sebagai jalan membentuk manusia yang kamil menjunjung tinggi nilai keadilan sebagai konsekuensi dari salah satu perannya sebagai khalifatullah di bumi, yaitu memberikan kemakmuran alam semesta. Salah satu aspek pendidikan yang dapat mengantarkan pada tujuan tersebut adalah pandangan multikulturalisme dalam pendidikan Islam. Tulisan ini ditujukan untuk melihat konsep dasar epistemologi pendidikan multikultural dalam Islam, yang pada akhirnya dapat diimplementasikan dalam proses pendidikan Islam. Metode yang digunakan dalam penulisan artikel ini adalah "literature review" tentang konsep multikulturalisme, dasar epistemologi multikulturalisme dan pendidikan multikultural dalam Islam. Hasil yang didapat dari penelitian ini adalah bahwa pendidikan multikultural mengedepankan aspek kesedarajatan dalam praktik pembelajaran. Nilai-nilai multikulturalisme tidak bertentangan dengan nilai-nilai Islam, bahkan dapat menghantarkan pencapaian tujuan pendidikan Islam, yaitu membentuk tatanan yang harmoni dalam kehidupan sosial masyarakat.

\section{Abstract}

Education as a means of developing human potential and the formation of a community order must be carried out with the principles of equality and justice. The principle is based on the inevitability that humans live within the sphere of difference. Islamic education is a way of forming human beings, we uphold the value of justice as a consequence of one of its roles as khalifatullah on earth, which is to give prosperity to the universe. One aspect of education that can deliver this goal is the view of multiculturalism in Islamic education. This paper is aimed at looking at the basic concepts of the epistemology of multicultural education in Islam, which ultimately can 
be implemented in the process of Islamic education. The method used in writing this article is the "literature review" on the concept of multiculturalism, the basis of the epistemology of multiculturalism and multicultural education in Islam. The results obtained from this study are that multicultural education emphasizes the aspects of harmony in learning practices. The values of multiculturalism do not conflict with the values of Islam, they can even lead to the achievement of the goals of Islamic education, namely forming a harmonious order in the social life of the community.

Keyword: Epistemology, Education, Multicultural, Islam

\section{PENDAHULUAN}

Pendidikan memiliki peranan penting dalam pembangunan nasional, karena melalui pendidikan suatu negara dapat memiliki generasi yang berkualitas, sehingga dapat memberikan kontribusi dalam perbaikan pembangunan negara. Sebagai komunitas yang besar, negara memiliki anggota dengan berbagai macam latar belakang dan status sosial. Dalam rangka pembangunan nasional tersebut sudah selayaknya pendidikan harus mampu mencerdaskan seluruh warga negara dengan prinsip keadilan dan kesetaraan.

Undang-Undang No. 20 Tahun 2003 Tentang Sistem Pendidikan Nasional menjelaskan bahwa pendidikan diselenggarakan secara demokratis dan berkeadilan serta tidak diskriminatif dengan menjunjung tinggi hak asasi manusia, nilai keagamaan, nilai kultural, dan kemajemukan bangsa. ${ }^{1}$ Prinsip tersebut sesuai dengan realita bangsa Indonesia sebagai negara yang plural, baik dilihat dari suku, agama, ras, kebudayaan, ataupun status sosial lainnya. Pendidikan sebagai transfer sosial menuju perbaikan seharusnya memberikan ruang kepada setiap perbedaan yang ada di dalam negara.

\footnotetext{
${ }^{1}$ UU No.20 Tahun 2003 Tentang Sistem Pendidikan Nasional, Bab III
} Pasal 4. 
Perbedaan merupakan sunnatullah atau kehendak Allah yang tidak perlu dijadikan beban oleh manusia. Perbedaan tidak seharusnya menjadi permasalahan dalam kehidupan sosial, akan tetapi perbedaan seharusnya dirawat secara bersama-sama dalam semangat pembangunan nasional. Berkenaan dengan perbedaan, Islam sendiri telah menjelaskan dalam Q.S Hud ayat 118:

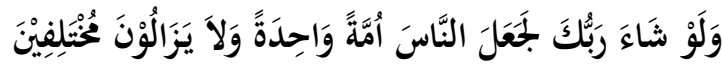

Artinya: "Sekiranya Tuhanmu menghendaki, tentu Dia menjadikan manusia umat yang satu, tetapi mereka senantiasa berselisih"

Ayat di atas memberikan konsekuensi bahwa manusia harus mampu menjalani kehidupan yang harmonis dalam lingkup perbedaan (multikulturalisme), baik perbedaan suku, ras, bahasa, bahkan agama. Perihal beragama, meskipun Islam menekankan kepada penganutnya untuk memiliki rasa yakin yang penuh atas agama Islam, tetapi kesadaran akan keberadaan agama lain juga perlu diwujudkan dengan semangat tasamuh dan hubungan baik sesama manusia.

Pandangan multikulturalisme di atas tidak bertentangan dengan nilai-nilai Islam. Menurut Abdul Karim, risalah agama diturunkan kepada umat manusia untuk mengembangkan cita-cita luhur, sebagai panduan ilahiyah bagi perwujudan tatanan makhluk yang damai, penuh rahmat, harmonis, adil dan sejahtera. ${ }^{2}$ Berdasarkan keterangan tersebut, maka pendidikan Islam sebagai salah satu sarana membentuk pribadi dan tatanan umat manusia seharusnya mampu mewujudkan pendidikan yang berprinsip pada nilai-nilai kemanusiaan, keadilan,

${ }^{2}$ Abdul Karim, "Pembaharuan Pendidikan Islam Multikulturalis", Jurnal Pendidikan Islam Ta'lim Vol.14, No.1, 2016. hal. 29-30. 
dan kesetaraan. Dalam hal ini diperlukan praktik pendidikan multikultural.

Untuk alasan di atas, maka tulisan ini ditujukan untuk melihat konsep dasar epistemologi pendidikan multikultural dalam Islam dan relevansinya dalam praktik pendidikan Islam.

\section{PEMBAHASAN}

\section{Konsepsi Pendidikan Multikultural}

Istilah multikultural menurut Tilaar, sebagaimana dikutip oleh M. Aji Nugroho terdiri dari dua kata, multi dan kultural. Multi berarti plural/bermacam-macam atau beragam, sedangkan kultural berasal dari kata cultural yang berarti kebudayaan, multikultural berarti beraneka ragam kebudayaan. Secara sederhana multikulturalisme dapat diartikan sebagai pengakuan atas keanekaragaman/ pluralisme budaya sebagai proses internalisasi nilai dalam suatu komunitas. ${ }^{3}$

Sedangkan menurut Suryana, konsep multikulturalisme tidak dapat dikatakan sama dengan konsep keberagaman suku atau kebudayaan suku bangsa yang merupakan ciri dari masyarakat majemuk karena multikulturalisme mengedepankan dan menekankan keanekaragaman kebudayaan dalam ranah kesederajatan. Blum, dalam Suryana menyatakan bahwa multikulturalisme meliputi sebuah pemahaman, penghargaan, dan penilaian terhadap budaya orang atau kelompok lain, serta sebuah penghargaan dan rasa ingin tahu tentang budaya atau etnis orang lain. Multikulturalisme mencakup penilaian atas kebudayaan orang lain, bukan dalam artian menyetujui seluruh aspek dan nilai dari kebudayaan tersebut, melainkan mencoba melihat

${ }^{3}$ Muhammad Aji Nugroho, "Pendidikan Islam Berwawasan Multikultural; Sebuah Upaya Membangun Pemahaman Keberagaman Inklusif pada Umat Muslim", Jurnal Mudarrisa, Vol.8, No.1, Juni 2016: 31-60, DOI:10.18326/mudarrisa. hal. 39. 
nilai dari kebudayaan tertentu untuk dapat diekspresikan bagi anggotaanggotanya. $^{4}$

Dalam konsep pendidikan, multikultural menurut Lawrence J. Saha sebagaimana dikutip oleh Tri Astutik Hastuti berarti suatu proses pendidikan yang melibatkan beberapa budaya, baik meliputi kebangsaan, etnik, bahasa, atau kriteria yang bersifat ras. Pendidikan tersebut dapat diwujudkan dalam program pendidikan formal atau informal, maupun langsung atau tidak langsung. Pendidikan multikultural diorientasikan untuk mewujudkan kesadaran akan toleransi, pengetahuan dan pemahaman yang mempertimbangkan perbedaan budaya, dan juga perbedaan maupun persamaan antar budaya serta kaitannya dengan pandangan dunia, nilai, konsep, keyakinan, dan sikap. ${ }^{5}$

Pemikiran tentang pendidikan multikultural di atas sejalan dengan pendapat Paulo Freire pakar pendidikan pembebasan, bahwa pendidikan bukan "menara gunding" yang mencoba menjauhi realitas sosial maupun budaya. Menurutnya, pendidikan harus dapat menciptakan sistem dan tatanan masyarakat yang terdidik dan berpendidikan, bukan sistem masyarakat yang hanya mengedepankan prestise sosial sebagai buah akan kekayaan dan kemakmuran. ${ }^{6}$

Multikulturalisme dalam pendidikan didasarkan pada rekomendasi dari UNESCO tentang pendidikan, bahwa; pertama, pendidikan seharusnya diarahkan dalam mengembangkan kemampuan untuk mengakui dan menerima nilai-nilai yang terdapat dalam

4 Yaya Suryana \& Rusdiana, "Pendidikan Multikultural; Suatu Upaya Penguatan Jati Diri Bangsa”, (Bandung: CV Pustaka Setia, 2015), hal. 194-195.

5 Tri Astutik Haryati, "Islam dan Pendidikan Multikultural", Jurnal Tadris, Vol. 4, No. 2, 2009. hal 160-161.

6 Yaya Suryana \& Rusdiana, "Pendidikan Multikultural; Suatu Upaya Penguatan Jati Diri Bangsa”.....hal. 196. 
keberagaman pribadi, jenis kelamin, masyarakat dan budaya serta kemampuan untuk berkomunikasi, bekerja sama dan berbagi dengan orang atau kelompok lain; kedua, pendidikan seharusnya dapat meneguhkan jati diri individu dan mendorong perpaduan gagasan dan penyelesaian-penyelesaian yang memperkokoh persatuan, perdamaian, persaudaraan dan solidaritas antara pribadi dan masyarakat; ketiga, pendidikan hendaknya dapat meningkatkan dan mengembangkan kemampuan menyelesaikan konflik dengan damai tanpa kekerasan. Karena itu, pendidikan seharusnya juga meningkatkan pengembangan kedamaian dalam pikiran siswa, dengan demikian mereka dapat membangun dengan lebih kokoh kualitas toleransi, kesabaran, dan kemauan untuk berbagi. ${ }^{7}$

Pencetus konsep pendidikan multikultural, James A. Bank, melihat pendidikan multikultural dari tiga aspek yaitu konsep, gerakan, dan proses. Dari aspeknya, pendidikan multikultural dapat dipahami sebagai ide atau gagasan yang memandang seluruh siswa tanpa memperhatikan gender, status sosial, etnik, ras, dan atau karakteristik budaya lainnya dari mereka - semua siswa memiliki kesempatan yang sama untuk belajar dalam kelas. Dari aspek gerakannya, pendidikan multikultural diartikan sebagai upaya untuk mengubah sekolah dan institusi pendidikan sehingga peserta didik dari berbagai kelas sosial, ras, gender dan kelompok-kelompok kultural memiliki kesempatan sama untuk belajar. Perubahan yang diupayakan tidak terbatas pada kurikulum, namun juga aspek lainnya seperti strategi, metode, manajemen, serta lingkungan pembelajaran. Dari sisi prosesnya, pendidikan multikultural diartikan sebagai proses dalam mencapai tujuan kesetaraan pendidikan dapat dicapai oleh seluruh

7 Abdul Karim, "Pembaharuan Pendidikan Islam Multikulturalis", Jurnal Pendidikan Islam Ta'lim Vol.14, No.1, 2016. hal. 30. 
peserta didik. Kesetaraan tersebut seperti keadilan dan kemerdekaan tidak mudah untuk dicapai, karena itu proses tersebutr harus berlangsung secara berkesinambungan. ${ }^{8}$

Sedangkan menurut Muzakkir, pada prinsipnya pendidikan multikultural adalah pendidikan yang menghargai perbedaan. Pendidikan yang senantiasa menciptakan struktur serta proses di mana setiap kebudayaan dapat melakukan ekspresi. Terdapat dua hal yang dapat diperhatikan untuk mewujudkan pendidikan multikultural, yakni: pertama, adalah dialog. Pendidikan multikultural mustahil dapat berlangsung tanpa dialog. Dalam proses pendidikan multikultural segala perbedaan dari kebudayaan menempati posisi yang sama. Dalam dialog niscaya terdapat persamaan dari pihak yang terlibat. Dengan proses dialog, diharapkan terjadi sumbangsih pemikiran yang pada gilirannya dapat memperkaya budaya atau peradaban yang bersangkutan. Kedua, adalah sikap toleransi. Toleransi merupakan sikap menerima bahwa orang atau kelompok lain berbeda dengan kita. Dialog maupun sikap toleransi merupakan satu kesatuan. Jika dialog adalah bentuknya, maka toleransi adalah isinya. Sikap toleransi diperlukan bukan hanya sebatas tataran konseptual, namun juga pada tingkat teknis operasional. ${ }^{9}$

Pendidikan multikultural ditujukan untuk memberikan kesetaraan pada peserta didik. Adapun tujuannya, menurut Suryana adalah untuk membantu peserta didik:

1. Menyadari dan mmahami latar belakang diri dan kelompok di dalam masyarakat

${ }^{8}$ Ibid., 161.

9 Muzakkir, "Perspektif Islam Tentang Pendidikan Multikultural”, Jurnal Pendidikan Islam Fakultas Tarbiyah dan Keguruan UIN Alauddin Makassar, Vol. VII, No. 1, Januari-Juni 2018. hal. 106. 
2. Menghormati dan mengapresiasi ke-bhineka-an kultur dan sosio-historis etnik

3. Menghapus sikap etnosentris dan penuh purbasangka

4. Memahami perbedaan sosial, psikologis, ekonomis, dan historis yang dapat menyebabkan terjadinya jarak, ketimpangan, keterasingan antar etnik

5. Menumbuhkan kemampuan untuk menganalisis secara lebih kritis terhadap masalah-masalah yang sering timbul secara demokratis melalui visi tentang masyarakat yang lebih baik, adil, dan bebas

6. Menumbuhkembangkan jati diri yang bermakna bagi setiap orang. ${ }^{10}$

Nilai-nilai pendidikan multikultural menurut Setya Raharja, dalam Suryana yaitu demokratis, humanisme, dan pluralisme. Nilai demokratisasi atau keadilan merupakan sebuah istilah yang menyeluruh dalam segala bentuk, baik keadilan budaya, politik, maupun sosial. Keadilan merupakan bentuk bahwa setiap manusia mendapatkan sesuatu yang dibutuhkan, bukan yang diingingkan. Nilai humanisme atau kemanusiaan merupakan pengakuan terhadap pluralitas dan keragaman pada manusia. Keragaman itu dapat berupa ideologi, paradigma, suku bangsa, agama, tingkat ekonomi, dan sebagainya. Sedangkan nilai pluralisme bangsa adalah pandangan yang mengakui adanya keragaman dalam suatu bangsa. Istilah plural mengandung arti berjenis-jenis, tetapi pluralisme tidak sebatas

10 Yaya Suryana \& Rusdiana, "Pendidikan Multikultural; Suatu Upaya Penguatan Jati Diri Bangsa”.....hal. 199. 
pengakuan terhadap hal tersebut, melainkan memiliki implikasiimplikasi politis, sosial, dan ekonomi. ${ }^{11}$

\section{Landasan Normatif Multikulturalisme dalam Islam}

Islam pada dasarnya merupakan seruan pada seluruh umat manusia, termasuk para pegikut agama-agama, untuk menuju satu cita bersama, yaitu kesatuan kemanusiaan (unity of humankind) tanpa perlu membedakan ras, warna kulit, kebudayaan dan agama. Hal tersebut berarti bahwa dominasi ras ataupun diskriminasi atas nama apapun adalah kekuatan antitesis terhadap tauhid, sehingga harus dinilai sebagai sebuah kemusyrikan sekaligus kejahatan atas kemanusiaan. $^{12}$

Islam memberikan pandangan terhadap perbedaan sebagai keniscayaan yang merupakan kehendak Allah swt. Allah telah menjelaskan di dalam Al quran tentang makna perbedaan umat manusia melalui beberaya ayat, di antaranya yaitu:

1. Q.S al-Hujuraat (49): 13

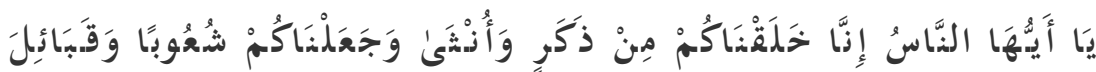

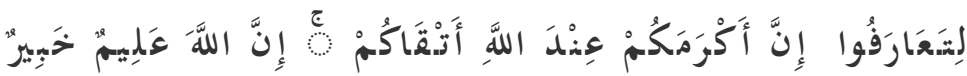

"Hai manusia sesungguhnya Kami menciptakan kamu dari seorang laki-laki dan seorang perempuan dan menjadikan kam berbangsa-bangsa dan bersuku-suku supaya kamu saling kenalmengenal. Sesungguhnya yang paling mulia di antara kamu di sisi Allah ialah yang paling bertakwa di antara kamu. Sesungguhnya Allah Maha Mengetahui lagi Maha Mengenal”.

${ }^{11}$ Ibid., hal. 201.

12 Zakiyuddin Baidhawy, "Pendidikan Agama Berwawasan Multikultural", (Jakarta: Penerbit Erlangga, 2005), hal.45. 
Menurut tafsir al-Misbah bahwa sesungguhnya Allah Swt menciptakan manusia dari seorang laki-laki dan seorang perempuan merupakan pengantar untuk menegaskan bahwa seluruh umat manusia memiliki derajat kemanusiaan yang sama disisi Allah swt. Tidak terdapat perbedaan antara golongan satu dengan golongan yang lain. Allah menjadikan manusia dengan berbagai suku, bangsa, ataupun kelompok. Mereka mendapat perlakuan yang sama oleh Allah swt. Tujuannya satu, yaitu "li ta "arafu" (untuk saling mengenal satu sama lain dengan baik). Pengantar tersebut memberikan kesimpulan bahwa "yang paling mulia diantara umat manusia disisi Allah swt. adalah yang paling bertakwa”. Dengan demikian, yang membedakan manusia satu dengan lainnya bukanlah terletak pada suku, ras, ataupun bahasanya, melainkan lebih kepada tingkat ketaqwaannya kepada Allah swt Tuhan semesta alam. ${ }^{13}$

2. Q.S Yunus (10): 99

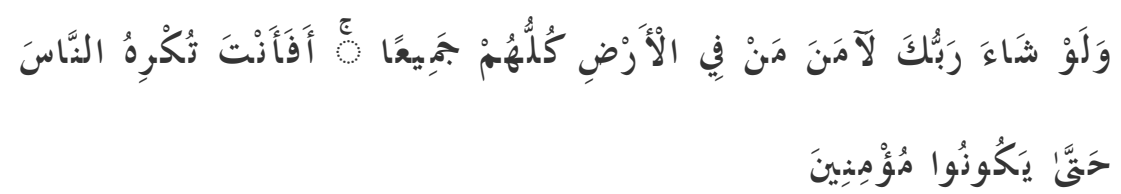

"Dan jika Tuhanmu menghendaki, tentulah beriman semua orang di muka bumi seluruhnya. Maka apakah kamu (hendak) memaksa manusia supaya mereka menjadi orangorang yang beriman semuanya?"

Ayat diatas menjelaskan bahwa, perbedaan menjadi hal yang niscaya bagi Allah swt. Adanya perbedaan merupakan sunnatullah sekaligus menjadi kebesaran dan kekuasaan Allah akan ciptaannya. Inilah yang membedakan antara keterbatasan kekuasaan manusia

${ }^{13}$ M. Quraish Shihab, "Tafsir Al Misbah; Pesan, Kesan, dan Keserasian Al Quran" Vol.13, (Jakarta: Lentera Hati, 2006), hal.260 
dengan kekuasaan Allah. dari hal-hal yang sangat kecilpun diantara semua makhluk-Nya di seantero dunia ini, tidaklah ada kesamaan antara satu dengan lainnya. Maka apakah kita (manusia) hendak memaksa manusia menjadi orang-orang yang beriman semua? Sesungguhnya itu semua tidak akan mampu untuk dilakukan, karena itu akan mengingkari pluralitas dan heterogenitas yang sudah menjadi ketentuan dan ketetapan Allah swt. ${ }^{14}$

3. Q.S al-Mumtahanah (60): 8.

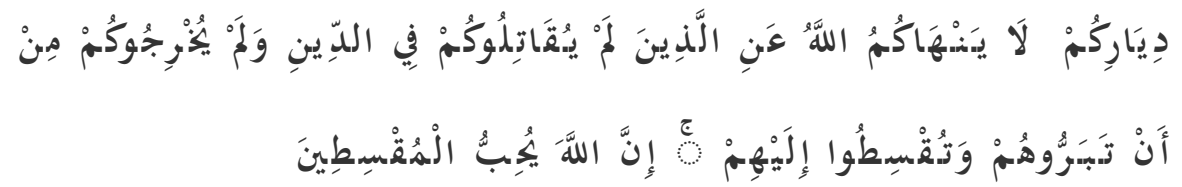

“Allah tidak melarang kamu untuk berbuat baik dan berlaku adil terhadap orang-orang yang tiada memerangimu karena agama dan tidak (pula) mengusir kamu dari negerimu. Sesungguhnya Allah menyukai orang-orang yang berlaku adil."

Ayat di atas sangat menekankan anjuran berlaku adil, keadilan dalam arti yang sangat luas, yakni keadilan dalam bidang politik, agama, hukum dan hak asasi manusia. Misalnya seorang pemimpin berlaku adil kepada rakyatnya, baik perorangan maupun kelompok. Terlepas dari itu, keadilan tidaklah memandang latar belakang dari individu ataupun golongan tertentu dalam hal suku, rasisme, budaya, dan agama. Tidak ada saling hegemoni antara kelompok mayoritas terhadap kelompok minoritas. Mendapatkan keadilan adalah hak semua individu dalam sebuah negara, bahkan dalam hal peperangan dan permusuhanpun Allah sangat

${ }^{14}$ M. Quraish Shihab, "Tafsir Al Misbah; Pesan, Kesan, dan Keserasian Al Quran” Vol.6, (Jakarta: Lentera Hati, 2006), hal. 164. 
menganjurkan hambanya untuk berlaku adil dan penuh kasih sayang terhadap musuhnya, karena diantara orang-orang yang bermusuhan itu terdapat rasa kemanusiaan, keadilan dan ketuhanan. ${ }^{15}$

Merujuk pada ayat-ayat di atas, ada beberapa poin yang menjadi prinsip beretika dalam menjalin hubungan di atas perbedaan, khususnya antar umat beragama, yaitu: pertama: prinsip egalitarianisme (al-musawat) yang memandang manusia ditakdirkan sama derajatnya; kedua: prinsip keadilan (al-'adalah) yang merupakan implikasi dari bertakwa dalam arti didak diskrimitatif, baik dalam pengelolaan sumber daya ekonomi, politik, sosial budaya, pendidikan maupun penerapan hukum; ketiga: prinsip toleransi (tasamuh) dan kompetisi dalam kebaikan (fastabiq al-khairat); keempat: prinsip saling menghormati, bekerjasama, dan pertemanan; kelima: prinsip koeksistensi damai (al-ta"ayusy al-silmi). Prinsip ini merupakan dasar hubungan antar manusia sesuai dengan arti genetik islam itu sendiri, yaitu perdamaian; keenam: dialog yang arifkonstruktif-transformatif (mujadalat bi al-hasan). ${ }^{16}$

Selain ayat-ayat Al quran di atas, terdapat landasan lain yang dapat menjadi referensi dalam membangun keharmonisan dalam perbedaan menurut Islam. Landasan tersebut adalah contoh langsung dari Nabi Muhammad saw dalam menyatukan masyarakat yang majemuk melalui sebuh perjanjian yang disebut sebagai "Piagam Madinah”.

Sejarah mencatat, negara Madinah menjadi contoh kongkret keserasian hidup bernegara dan beragama. Sejumlah pengamat Barat pun mengakui, Piagam Nabi itu merupakan sebuah konsensus

15 Tejo Waskito, "Pendidikan Multikultural dalam Al quran", Jurnal Pendidikan Islam, hal. 12.

${ }^{16}$ Iibid., hal. 18. 
bersama antara berbagai golongan, ras, suku, maupun agama, yang paling demokratis sepanjang sejarah. Menurut Syafi'i Maarif sebagaimana dikutip Hery Sucipto, Piagam Madinah telah mewariskan kepada kita prinsip-prinsip yang tahan banting dalam menata masyarakat pluralistik yang harmonis berlandaskan moral religius yang kokoh dan anggun. Dengan Piagam Madinah, Rasulullah membuktikan bahwa Islam merupakan agama rahmat bagi seluruh umat manusia. Pesan-pesan Islam pun dapat diterima oleh seluruh kalangan, termasuk para pemeluk Yahudi maupun Nasrani, sehingga tercipta tatanan yang adil dan damai. ${ }^{17}$

Sebagai sebuah produk peradaban, Piagam Madinah telah banyak memberi pelajaran dan nilai-nilai penting tentang bagaimana umat beragama membangun sebuah tatanan masyarakat yang adil dan humanis. Tatanan yang diidamkan tersebut dapat dipercaya karena esensi dari piagam dapat memenuhi syarat-syarat yang memungkinkan tercapainya sebuah konstelasi masyarakat yang berkeadilan serta berkeadaban. Piagam Madinah merupakan jendela bagaimana umat manusia membangun suatub sistem peradaban yang tercerahkan serta memberi manfaat bagi semua orang.

Menurut Prof Dr Azyumardi Azra, dalam Hery Sucipto, setidaknya ada dua nilai penting yang dapat diambil dari Piagam Madinah dan masih relevan hingga saat ini. Pertama, Nabi meletakkan prinsip integrasi sosial dan politik dalam sebuah negara Madinah. Ini merupakan nilai penting dan merupakan peristiwa sejarah yang luar biasa mengingat masyarakat Madinah saat itu bersifat majemuk. Kedua, adalah dasar penghormatan yang kokoh

17 Hery Sucipto \& Indah Wulaningsih, dalam Mohammad Shoelhi, “Demokrasi Madinah; Model Demokrasi Cara Rasulullah", (Jakarta: Republika, 2003), hal.35. 
bagi sebuah kehidupan yang toleran dengan menjamin hak-hak kaum non-Muslim. Ini diwujudkan dengan perlindungan pada kehidupan dan harta benda mereka. Inilah sumbangan terbesar Piagam Madinah yang kemudian diadopsi oleh kehidupan modern dalam wujud hak asasi manusia. $^{18}$

\section{Ontologi Pendidikan Islam Multikultural}

\section{Hakikat Multikulturalisme Pendidikan Islam}

Pendidikan di dalam Islam berfungsi untuk membimbing serta mengarahkan umat manusia untuk mampu mengemban perintah atau amanah dari Allah, yaitu menjalankan tugas hidup di muka bumi sebagai abdullah, yang harus taat terhadap setiap aturan dan kehendak Allah, mengabdi hanya kepada Allah maupun sebagai khalifah Allah, baik menyangkut pelaksanaan tugas kekhalifahan terhadap diri sendiri, rumah tangga, masyarakat dan tugas ke-khalifahan terhadap alam. Menurut Muhaemin, dalam Sopiah di antara tugas ke-khalifahan dalam masyarakat adalah mewujdukan persatuan umat, saling membantu dalam kebaikan, menegakkan keadilan di dalam masyarakat, bertanggungjawab dalam amar makruf nahi munkar dan berlaku baik terhadap sebagian masyarakat yang lemah. Sedangkan tugas ke-khalifahan yang berhubungan dengan alam di antaranya yaitu membudayakan alam, mengalamkan budaya serta mengislamkan kultur. ${ }^{19}$

Pendidikan Islam menjadi usaha dalam menggali dan mengembangkan potensi siswa untuk beriman, bertakwa dan

${ }^{18}$ Ibid., 38.

19 Sopiah, "Pendidikan Multikultural dalam Pendidikan Islam", Jurnal Forum Tarbiyah, Vol.7, No.2, Desember 2009. hal.163. 
berakhlak yang mulia atau mewujudkan siswa menjadi Insan Kamil. Tidak mudah untuk mencapai Insan kamil, hal itu memerlukan persiapan dan pembelajaran hidup secara maksimal, di mana mereka yang sudah masuk katagori Insan Kamil, secara manusiawi telah sempurna dan relatif tidak memiliki problem ketuhanana ataupun kemanusiaan. Sudah optimal dalam hablum min Allaah wa hablun min an-nas, atau manusia yang telah dapat mengoptimalkan dan menggunakan Multiple Intelegence-nya secara seimbang di dalam setiap aspek kehidupan.

Menurut Sopiah, pendidikan Islam di Indonesia adalah bagian dari pendidikan nasional, sehingga pendidikan Islam di Indonesia-pun seharusnya mampu mewujudkan wawasan pendidikan multikultural. Sesungguhnya Islam telah "beragam" sejak kelahirannya, setidaknya hal tersebut terdapat dalam catatan sejarah. Pendidikan Islam-pun memiliki keberagaman, maka orang Islam tidak akan dikatakan mengingkari sejarah jika mengimplementasikan pendidikan multikultural. Pada kenyataannya untuk mengajarkan Islam, seorang guru atau dosen telah terbiasa mengimplementasikan wawasan multikultural. ${ }^{20}$

Menurut Muhammad Ali, konsep pluralis-multikultural dalam pendidikan agama dapat menjadi bekal penting bagi kalangan terpelajar dan masyarakat luas untuk dapat menghargai segala perbedaan, menghormati secara tulus, terbuka, komunikatif, dan tidak saling menaruh curiga, selain untuk meningkatkan keimanan dan ketakwaan. Pendidikan pluralis bukan berarti mengajarkan siswa untuk menjalankan agama dengan kemauannya

\footnotetext{
${ }^{20}$ Ibid., hal. 164.
} 
sendiri, tanpa tanggung jawab dan rasa tulus, tetapi justru mengajarkan mereka untuk taat dalam beragama, tanpa menghilangkan ke-khasan keagamaan masing-masing. Wajah agama yang diwujudkan dalam pendidikan pluralis adalah agama yang moderat serta ramah.

Pendidikan pluralis-multikultural merupakan proses penyadaran untuk memiliki wawasan pluralis (secara agama) dan sekaligus wawasan multikultural (secara budaya). Pendidikan pluralis-multikultural harus dimaknai sebagai bagian dari usahausaha komprehensif mencegah, menghindari dan menanggulangi konflik atau permasalahan yang bernuansa etnis maupun agama di waktu mendatang. ${ }^{21}$

Islam adalah ajaran Tauhid, hal tersebut mengandung pengertian adanya suatu orde yang satu sekaligus menyeluruh. Dengan arti lain, terdapat hukum abadi yang bersifat universal. Menurut Marcel A. Boisard dalam Tri Astutik Haryati, hukum tersebut berawal dari sebuah keyakinan bahwa manusia merupakan satu dan tercipta karena satu kehendak yang sama, yaitu Tuhan pencipta alam. Kesadaran tersbeut hanya dapat tumbuh pada manusia yang memiliki kesadaran akan prinsip-prinsip moral yang dapat menyatukan perasaan dan merupakan dasar dari kebajikan universal. $^{22}$

Menurut Hans Kung, dalam ST. Sunardi, bahwa posisi atau kedudukan agama harus dilihat melalui dua arah, yaitu dari luar

21 Muhammad Ali, "Teologi Pluralis-Multikultural: Menghargai Kemajemukan Menjalin Kebersamaan”, (Jakarta: Kompas, 2003), hal. 100-102.

${ }^{22}$ Tri Astutik Haryati, "Islam dan Pendidikan Multikultural", Jurnal Tadris, Vol. 4, No. 2, 2009. Hal. 168. 
dan dari dalam. Pertama, melihat agama dari luar, yaitu mengakui akan adanya berbagai agama yang benar. Hal tersbeut merupakan dimensi relatif suatu agama. Agama-agama tersbeut mempunyai satu tujuan yaitu keselamatan (dengan konsep berbeda-beda) dan melalui jalan yang berbeda-beda. Lewat perbedaan tersebut, agama-agama dapat saling memperkaya satu sama lain. Kedua, melihat agama dari dalam, yaitu mengakui akan adanya satu agama yang benar, hal tersebut merupakan dimensi mutlak dari suatu agama. $^{23}$

Paham multikulturalisme, meskipun berasal dari keilmuan Barat, akan tetapi tidak bertentangan dengan nilai-nilai Islam dengan perspektif yang berbeda. Jika niali multikultural perspektif Barat berasal dari filsafat murni, nilai multikultural dalam Islam bersumber dari wahyu. Kedua perspektif tersebut memiliki karakteristik masing-masing. Achmad Rois membedakan karakteristik kedua perspektif tersebut dengan bagan di bawah ini: $:^{24}$

\begin{tabular}{|l|l|l|}
\hline Karakteristik & $\begin{array}{l}\text { Nilai multikultural } \\
\text { perspektif barat }\end{array}$ & $\begin{array}{l}\text { Nilai multikultural } \\
\text { perspektif Islam }\end{array}$ \\
\hline $\begin{array}{l}\text { Bertumpu pada } \\
\text { prinsip demokrasi, } \\
\text { keadilan, dan } \\
\text { kesetaraan }\end{array}$ & $\begin{array}{l}\text { Demokrasi, kesetaraan } \\
\text { dan keadilan }\end{array}$ & $\begin{array}{l}\text { Al-Musyawarah, al- } \\
\text { musawah dan al-'adl }\end{array}$ \\
\hline Berorientasi pada & Kemanusiaan, & Hablum min an-nas, \\
\hline
\end{tabular}

${ }^{23}$ ST. Sunardi, "Dialog: Cara Baru Beragama Sumbangan Hans Kung Bagi Dialog Antar Agama”, dalam Seri DIAN I Dialog, Kritik dan Identitas Agama, (Yogyakarta: Pustaka Pelajar dan DIAN, 1994), hal. 66-67.

24 Achmad Rois, "Pendidikan Islam Multikultural; Telaah Pemikiran Muhammad Amin Abdullah", Jurnal Episteme, Vol.8, No.2, Desember 2013. hal. 312. 


\begin{tabular}{|l|l|l|}
\hline $\begin{array}{l}\text { kemanusiaan, } \\
\text { kebersamaan dan } \\
\text { kedamaian }\end{array}$ & $\begin{array}{l}\text { kebersamaan, dan } \\
\text { kedamaian }\end{array}$ & $\begin{array}{l}\text { al-ta'aruf, al-ta'awun } \\
\text { dan al-salam }\end{array}$ \\
\hline $\begin{array}{l}\text { Mengembangkan } \\
\text { sikap untuk } \\
\text { mengakui, menerima } \\
\text { serta menghargai } \\
\text { keragaman }\end{array}$ & $\begin{array}{l}\text { Toleransi, empati, } \\
\text { simpati dan solidaritas } \\
\text { sosial }\end{array}$ & $\begin{array}{l}\text { Al-ta'addudiyat, al- } \\
\text { tanawwu', al-tasamuh, } \\
\text { al-rahmah, al-'afw } \\
\text { dan al-ihsan }\end{array}$ \\
\hline
\end{tabular}

Bagan: Karakteristik Multikulturalisme Perspektif Barat dan Islam

Berkenaan dengan paham multikulturalisme, Amin Abdullah sebagai pencetus gagasan integratif-interkonektif di UIN Sunan Kalijaga memandang perlunya pengahapusan dikotomi antara "ilmu pengetahuan" dan "agama", hal tersebut berarti juga seruan kepada umat masyarakat untuk saling bersinergi tanpa harus melihat perbedaan latar belakang budaya maupun agama dalam memajukan kehidupan masyarakat, khususnya dalam proses pendidikan.

Menurut Amin Abdullah, dalam Achmad Rois, bahwa mengingkari keberadaan dari tradisi-tradisi agama di muka bumi merupakan pekerjaan sia-sia. Masing-masing agama memiliki hak hidup yang sama; masing-masing memiliki cara dalam mempertahankan tradisi ataupun identitasnya sendiri-sendiri melalui berbagai cara yang dapat dilakukan. Cara yang paling efektif adalah melalui jalur pendidikan karena dalam prosesnya pendidikan merupakan langkah dalam meneruskan, melanggengkan, ataupun mengonservasi tradisi dari satu generasi ke genari selanjutnya, dari masa satu ke masa selanjutnya.

Dari sudut pandang efektivitas, Amin Abdullah memiliki anggapan bahwa untuk mencapai tujuan yang ideal tersebut, yaitu 
"mengalih generasikan kebudayaan", pendidikan menjadi salah satu cara yang paling efektif. Dalam hal ini pendidikan adalah sebuah media yang mampu melahirkan generasi yang memiliki pandangan ke depan dalam menghadapi realitas. Generasi yang dapat menjadikan keberagaman sebagai bagian yang harus dimaknai secara positif dan konstruktif. Karena pendidikan merupakan proses yang sistemik dan disertai tingkat penyebaran yang merata di berbagai wilayah. Lembaga-lembaga pendidikan dari berbagai jenis, jenjang dan jalur telah menyebar secara luas di sebagian besar wilayah Indonesia.

Pendapat yang disampaikan oleh Amin Abdullah tersebut menjelaskan bahwa terdapat dua hal yang harus menjadi perhatian dan fokus utama bagi para pendidik. Pertama, pendidik harus mampu dalam menyampaikan, memahamkan hingga mewariskan tradisi yang telah diyakini sebagai sebuah kebenaran yang mutlak. Penyampaian pengetahuan ini harus dibarengi melalui pemaparan dari tradisi yang ada secara historis dan tekstual (nash) sehingga pengetahuan danpemahaman yang diperoleh para siswa dapat diterima secara utuh dan tidak berat sebelah. Penyampaian pengetahuan tersebut, khususnya pengetahuan akan keagamaan dapat berimplikasi pada titik fokus selanjutnya. Kedua, pendidik harus mampu memberikan pemahaman kepada siswa untuk mampu mengakui, menerima serta menghargai keberadaan kelompok lain dengan semua tradisi dan keyakinan yang menyertainya. Sehingga hak-hak keberlangsungan hidup kelompok tertentu tidak mungkin 
berbenturan satu sama lain. Kedua fokus tersebut yang seharusnya menjadi perhatian khusus bagi para pendidik di era multikultural. ${ }^{25}$

Menurut Baidhawy, konflik antar agama mampu diredam manakala mampu menghadirkan pendidikan agama berwawasan multikultural, hal ini dikarenakan pendidikan multikultural memiliki karateristik; (1) belajar hidup dalam perbedaan; (2) membangun rasa saling percaya; (3) memelihara rasa saling pengertian; (4) menjunjung sikap saling menghargai; (5) terbuka dalam berpikir; (6) apresisasi dan interdepedensi; (7) resolusi atas konflik dan rekonsiliasi nirkekerasan. ${ }^{26}$ Melalui karakteristik tersebut, proses pendidikan agama dapat menumbuhkan rasa saling empati. Selain itu, epmat pilar pendidikan UNESCO juga dapat terpenuhi, yang tidak hanya bersandar pada learning to know, learning to do, learning to be, tetapi juga learning to live together.

2. Pendekatan Induktif-Partisipatif Pendidikan Islam Multikultural

Terdapat perbedaan yang mendasar antara pendekatan induktif-partisitatif dan deduktif-normatif, kaitannya sebagai upaya dalam pembelajaran agama, guna membentuk pemahaman dan sikap siswa yang berwawasan multikulturalisme. Pendekatan deduktif secara etimologi adalah proses penarikan kesimpulan dari pernyataan-pernyataan (premis-premis), dimana tercapainya suatu kesimpulan yang pasti betul dengan aturan-aturan logika, kemudian berpegang teguh pada norma atau kaidah yang berlaku. Kemudian secara terminologi, deduktif (teologis) adalah cara pandang yang berawal dari keyakinan yang diyakini benar serta mutlak adanya

${ }^{25}$ Ibid., hal. 316-319.

${ }^{26}$ Zakiyuddin Baidhawy, "Pendidikan Agama Berwawasan hal. 78-84. 
yaitu ajaran dari Tuhan, sedangkan normatif yaitu suatu pendekatan yang melihat agama dari sisi ajaran pokoknya dan murni dari Tuhan, di dalamnya belum ada penalaran manusia. Jadi deduktifnormatif merupakan pendekatan dalam mempelajari agama yang berlandaskan pada ajaran agama yang absolut. Sedangkan pengertian induktif yaitu pendekatan dalam studi tentang agama, tanpa berdasar pada teori-teori formal dan abstrak, sebagai usaha untuk membebaskan diri dari kungkungan. Kemudian partisipatif adalah pendekatan yang memiliki pandangan bahwa masyarakat adalah selain menjadi objek, tetapi juga sebagai subjek yang berupaya memahami diri sendiri. Dalam artian, pendekatan induktif-partisipatif adalah upaya untuk membebaskan diri dari doktrin atau ajaran agamanya yang bersifat formal atau dogmatis, untuk dapat mengaktualisasikan diri secara bebas, tanpa terkait dengan aturan-aturan Agama. ${ }^{27}$

Pembelajaran agama menurut pendidikan multikulturalisme, yaitu untuk membentuk sikap dan pemahaman siswa yang multikulturalis melalui pendekatan induktif-partisipatif, dengan mengarahkan tujuan pembelajarannya kepada tiga ranah yaitu pertama: Kognitif, harapannya supaya membentuk pemahaman tentang berbagai agama serta mempertemukan dan menyatukan nilai-nilai universal yang terdapat pada masing-masing agama, kemudian yang kedua: Afektif, melalui ranah ini siswa akan memahami keberadaan agama lain. Dan yang ketiga: Psikomotorik, pada tataran ini, siswa dapat menjalankan agamanya sebatas dari sisi historis dan profan saja yang mengabaikan aspek normativitas

27 Abdul Kohar Umar, "Pendidikan Agama Berbasis Multikultiralisme; Studi Kritis", Jurnal At-Ta'dib, Vol. 7, No.2, Desember 2012. hal. 297. 
dan sakralitas. Senada dengan hal tersbeut, Amin Abdullah mengatakan bahwa, melalui pendekatan induktif-partisipatif, diharapkan terbangun sebuah pemahaman yang mampu memahami keragaman, dan tidak sebatas memahami ajaran agama secara sakral dan normatif, akan tetapi penting mempelajari dari aspek yang profan, dan aspek historis. Tujuannya, dapat memahami keberadaan agama lain dan berusaha memahami perbedaan serta persamaan, guna tercapainya kerukunan dalam kehinekaan. Sehingga ketika berhadapan dengan pemeluk agama lain akan muncul rasa simpati dan saling pengertian, keberagamaan seperti itulah yang menjadi tujuan pembelajaran agama dalam pendidikan multikulturalisme, sesuai dengan pendekatan yang digunakan. Pada akhirnya, siswa mengekspresikan potensinya secara bebas dan kritis, tidak terdapat lagi kekangan ajaran agama yang bersifat normatif, sesuai dengan doktrin yang diperoleh dari pendidikan agama di sekolah, dampak tersebut merupakan sebuah kenicayaan, untuk mencapai kebebasan maupun kemerdekaan dalam mengapresiasi pengalaman keberagamaan. ${ }^{28}$

\section{Kritik Terhadap Pendidikan Islam Multikultural}

Permasalahan mendasar pendidikan Islam multikultural adalah dalam konsep ketuhanan. Konsep ketuhanan dalam Islam bersifat final dan otentik, hal ini berbeda dengan konsep ketuhanan di agama lain. Sedangkan pendidikan multikultural mementingkan pendidikan keagamaan dibanding dengan pendidikan agama. Ketika keagamaan lebih dipentingkan maka pendidikan agama Islam perspektif multikulturalisme sebatas pendidikan agama yang mengajarkan nilai-

\footnotetext{
${ }^{28}$ Ibid., hal.297-298.
} 
nilai umum (universal) yang terdapat di semua agama, seperti nilai kemanusiaan, keadilan, kesetaraan, dan bersikap baik kepada setiap orang. Namun, kalau pendidikan agama konteks pendidikan Islam yang diajarkan adalah: Tauhid, untuk mengetahui Dzat dan sifat Allah, Fikih, untuk mengetahui hukum ibadah dan muammalah, dan selanjutnya mengajarkan Akhlak Al-Karimah seperti syukur, sabar, dermawan, jujur, ikhlas, adab bergaul dengan sesama; kemudian diajarkan pula akhlak tercela seperti dengki, iri, sombong, riya, marah, permusuhan, benci, kikir dan sebagainya. ${ }^{29}$

Dengan demikian, pendidikan multikulturalisme tidak sepenuhnya dapat dijadikan sebagai alternatif dalam pelajaran PAI sebab kandungan pluralisme agama, humanisme, dan demokrasi yang jika ditafsirkan secara bebas (liberal) maka akan mengancam rusaknya Aqidah dan moral atau akhlak siswa, serta rusaknya komponen dari aspek yang terdapat dalam Pendidikan Islam. ${ }^{30}$

Selain pemahaman di atas, multikulturalisme dalam Islam juga memiliki batasan-batasan tertentu. Batasan tersebut merupakan filter agar pemahaman multikultralisme tidak disalahartikan dan diwujudkan ke dalam perilaku-perilaku yang berlawanan dengan nilai Islam. Sebagai contoh, sikap toleransi terhadap budaya orang lain tidak berarti memberikan kebebesan terhadap budaya yang menyimpang dari sebagian masyarakat, seperti LGBT, pergaulan bebas, perjudian dan sebagainya. Batasan tersebut bukan berarti menunjukkan ekslusivisme Islam, namun sebagai penegakan prinsipprinsip Islam yang berdasar pada nilai Tauhid.

${ }^{29}$ Abdul Kohar Umar, "Pendidikan Agama Berbasis Multikultiralisme; Studi Kritis”, Jurnal At-Ta'dib, Vol. 7, No.2, Desember 2012.

${ }^{30}$ Ibid., 


\section{REFERENSI}

Ali, Muhammad. "Teologi Pluralis-Multikultural: Menghargai Kemajemukan Menjalin Kebersamaan", Jakarta: Kompas, 2003.

Baidhawy, Zakiyuddin. "Pendidikan Agama Berwawasan Multikultural", Jakarta: Penerbit Erlangga, 2005.

Haryati, Tri Astutik. "Islam dan Pendidikan Multikultural”, Jurnal Tadris, Vol. 4, No. 2, 2009.

Karim, Abdul. "Pembaharuan Pendidikan Islam Multikulturalis", Jurnal Pendidikan Islam Ta'lim Vol.14, No.1, 2016.

Muzakkir. "Perspektif Islam Tentang Pendidikan Multikultural", Jurnal Pendidikan Islam Fakultas Tarbiyah dan Keguruan UIN Alauddin Makassar, Vol. VII, No. 1, Januari- Juni 2018.

Nugroho, Muhammad Aji. "Pendidikan Islam Berwawasan Multikultural; Sebuah Upaya Membangun Pemahaman Keberagaman Inklusif pada Umat Muslim”, JurnalMudarrisa,Vol.8,No.1,Juni2016:31-6 DOI:10.18326/mudarrisa

Rois, Achmad. "Pendidikan Islam Multikultural; Telaah Pemikiran Muhammad Amin Abdullah", Jurnal Episteme, Vol.8, No.2, Desember 2013.

Shihab, M. Quraish, "Tafsir Al Misbah; Pesan, Kesan, dan Keserasian Al Quran” Vol.13, Jakarta: Lentera Hati, 2006.

Sopiah, "Pendidikan Multikultural dalam Pendidikan Islam", Jurnal Forum Tarbiyah, Vol.7, No.2, Desember 2009.

Sucipto, Hery \& Indah Wulaningsih, dalam Mohammad Shoelhi, "Demokrasi Madinah; Model Demokrasi Cara Rasulullah", Jakarta: Republika, 2003.

Sunardi, ST "Dialog: Cara Baru Beragama Sumbangan Hans Kung Bagi Dialog Antar Agama", dalam Seri DIAN I Dialog, Kritik dan Identitas Agama, Yogyakarta: Pustaka Pelajar dan DIAN, 1994

Suryana, Yaya \& Rusdiana, "Pendidikan Multikultural; Suatu Upaya Penguatan Jati Diri Bangsa", Bandung: CV Pustaka Setia, 2015.

Umar, Abdul Kohar, "Pendidikan Agama Berbasis Multikultiralisme; Studi Kritis", Jurnal At-Ta'dib, Vol. 7, No.2, Desember 2012

UU No.20 Tahun 2003 Tentang Sistem Pendidikan Nasional, Bab III Pasal 4.

Waskito, Tejo, "Pendidikan Multikultural dalam Al quran", Jurnal Pendidikan Islam 